\title{
SISTEM PENDUKUNG KEPUTUSAN \\ UNTUK MEMILIH USAHA WARALABA MAKANAN MENGGUNAKAN METODE TOPSIS
}

Oleh :

Meri Azmi

Jurusan Teknologi Informasi Politeknik Negeri Padang Kampus Unand Limau Manis Padang 25163. Telp. 0751-72590, Fax. 0751-72576. E-mail : pnp@polinpdg.ac.

\section{ABSTRACT}

Large number of franchises that will be selected as well as indicators of many criteria, it is necessary to build a decision support system that will help decide which franchise to choose. The model used in the decision support system is a Multiple Attribute Decision Making (MADM) and to perform calculations on the case MADM method in finding the best alternative based on the criteria specified use traditional methods TOPSIS (Technique for Order Preference by Similarity to Ideal Solution) to perform the calculations. TOPSIS method is chosen as the method is based on the concept that the best alternative was chosen not only has the shortest distance from the positive ideal solution, but also has the longest distance from the negative ideal solution.

Keywords : TOPSIS, MADM, Decision Support System

\section{PENDAHULUAN}

Membuka usaha sendiri adalah hal yang patut dipertimbangkan untuk memperoleh penghasilan dalam menopang kebutuhan dan biaya hidup saat ini. Tentunya ada berbagai macam jenis usaha yang dapat dijadikan pilihan dalam mengembangkan usaha. Mengingat perlu pengetahuan dan pengalaman tertentu untuk menjalani usaha tertentu, maka banyak orang yang lebih memilih usaha dengan sistem waralaba, karena usaha waralaba sudah memiliki standar dan merk tersendiri. Sehingga tidak harus mulai dari awal perancangan usaha dan prosedur awal lainnya. Tak heran kalau saat ini bermunculan banyak sekali usaha waralaba, baik yang memiliki kesamaan sistem maupun berbeda.

Bagi orang yang baru didunia usaha tentu akan mengalami kesulitan dalam memilih usaha waralaba yang tepat. Dalam memilih, ada kriteria kriteria yang dipertimbangkan dan masing masing orang memiliki kriteria yang berbeda tingkat kepentingan nya. Untuk memilih waralaba makanan misalnya, pengambil keputusan dihadapkan dengan banyaknya hal hal atau kriteria yang harus dipertimbangkan. Kriteria tersebut diantaranya adalah Jenis Makanan Waralaba, Cakupan Jaringan Waralaba, Lama Waralaba Berada Dalam Bisnis, Posisi Waralaba Dalam Industri, Tingkat Keuntungan dan Kondisi Keuangan Waralaba, Tingkat Pertumbuhan Waralaba, Kerentanan Terhadap Fluktuasi Ekonomi, Syarat Modal Untuk Memulai, Persyaratan Inventory, Jumlah Karyawan, Pelatihan atau Pendidikan Khusus, Fasilitas Desain dan Konstruksi, Dukungan Grand Opening, 
Dukungan Operasional Yang Berkesinambungan, Franchise Fee, Pembiayaan Sebuah Waralaba, dan Bantuan Pemilihan Lokasi.

Dengan banyaknya jumlah waralaba yang akan dipilih serta indikator kriteria yang banyak juga, maka perlu dibangun sebuah sistem pendukung keputusan yang akan membantu memutuskan waralaba yang akan dipilih. Model yang digunakan dalam sistem pendukung keputusan ini adalah Multiple Attribute Decision Making (MADM) dan untuk melakukan perhitungan metode MADM pada kasus tersebut dalam mencari alternatif terbaik berdasarkan kriteria-kriteria yang telah ditentukan mengggunakan metode TOPSIS (Technique for Order Preference by Similarity to Ideal Solution) untuk melakukan perhitungan. Metode TOPSIS ini dipilih karena metode ini didasarkan pada konsep dimana alternatif terpilih yang terbaik tidak hanya memiliki jarak terpendek dari solusi ideal positif, namun juga memiliki jarak terpanjang dari solusi ideal negatif.

Berdasarkan latar belakang di atas dapat dirumuskan permasalahan yang akan diselesaikan yaitu bagaimana merancang sebuah sistem pendukung keputusan menggunakan MADM (Multiple Attribute Decission Making) dengan metode TOPSIS (Technique for Order Preference by Similarity to Ideal Solution ) untuk menentukan waralaba yang dipilih berdasarkan bobot dan kriteria yang sudah ditentukan. Dengan menggunakan sebuah aplikasi untuk membantu menyelesaikan persmasalahan sehingga jauh lebih mudah dan efisien.

Pada penelitian ini diperlukan batasan-batasan agar sesuai dengan apa yang sudah direncanakan sebelumnya sehingga tujuan penelitian dapat tercapai. Adapun batasan masalah yang di bahas pada penelitian ini adalah: a. Jenis Waralaba yang dipilih adalah waralaba lokal yang bergerak dibidang makanan dan dengan modal dibawah Rp.15.000.000 atau sama dengan Rp.15.000.000,-

b. Kriteria yang dipakai dalam paper ini hanya 6 kriteria yaitu: Lama Berada Dalam Bisnis, Ketersediaan bahan baku makanan, Syarat Modal Untuk Memulai, Jumlah Karyawan, Franchise Fee, Biaya Operasional waralaba.

c. Metode pengambilan data diperoleh dengan quesioner dan pengumpulan data melalui web dan brosur tentang kerjasama dan pembagian fee waralaba bersangkutan.

Tujuan penelitan ini adalah membangun suatu model pengambilan keputusan mengunakan Multiple Attribute Decision Making (MADM) dengan metode TOPSIS (Technique for Order Preference by Similarity to Ideal Solution ) untuk menentukan waralaba yang dipilih berdasarkan kriteria kriteria serta bobot yang sudah ditentukan.

\section{TINJAUAN PUSTAKA}

\section{FRANCHISE}

Definisi Franchise (Waralaba): Menurut Blake \& Associates (Blake, 1996), kata franchise berasal dari bahasa Perancis kuno yang berarti bebas. Pada abad pertengahan franchise diartikan sebagai hak utama atau kebebasan (Sewu, 2004, p. 15). Menurut Queen (1 993:4-5) franchise adalah kegiatan pemberian lisensi dari pemegang usaha (franchisor) kepada pembeli merek usaha (franchisee) untuk berusaha dibawah nama dagang franchisor berdasarkan kontrak dan pembayaran royalti.

Menurut Winarto (1995, p. 19) Waralaba atau franchise adalah hubungan kemitraan yang usahanya kuat dan sukses dengan usahawan yang relatif baru atau lemah dalam usaha tersebut dengan tujuan saling menguntungkan 
khususnya dalam bidang usaha penyediaan produk dan jasa langsung kepada konsumen.

Jenis/Bentuk Franchise Menurut Mohammad Su'ud ( 1994:4445) bahwa dalam praktek franchise terdiri dari empat bentuk:

1. Product Franchise, Suatu bentuk franchise dimana penerima franchise hanya bertindak mendistribusikan produk dari partnernya dengan pembatasan areal.

2. Processing or Manufacturing Franchise, Jenis franchise ini memberikan hak pada suatu badan usaha untuk membuat suatu produk dan menjualnya pada masyarakat, dengan menggunakan merek dagang dan merek franchisor. Jenis franchise ini seringkali ditemukan dalam industri makanan dan minuman.

3. Bussiness Format atau System Franchise, Franchisor memiliki cara yang unik dalam menyajikan produk dalam satu paket, seperti yang dilakukan oleh Mc Donald's dengan membuat variasi produknya dalam bentuk paket.

4. Group Trading Franchise, Bentuk franchise yang menunjuk pada pemberian hak mengelola toko-toko grosir maupun pengecer yang dilakukan toko serba ada.

Sistem Pendukung Keputusan

Sistem Pendukung Keputusan sebagai sebuah sistem berbasis komputer yang membantu dalam proses pengambilan keputusan. Sistem Pendukung Keputusan sebagai sistem informasi berbasis komputer yang adaptif, interaktif, fleksibel, yang secara khusus dikembangkan untuk mendukung solusi dari pemasalahan manajemen yang tidak terstruktur untuk meningkatkan kualitas pengambilan keputusan.
Dengan demikian dapat ditarik satu definisi tentang Sistem Pendukung Keputusan yaitu sebuah sistem berbasis komputer yang adaptif, fleksibel, dan interaktif yang digunakan untuk memecahkan masalah-masalah tidak terstruktur sehingga meningkatkan nilai keputusan yang diambil. (Khoirudin, 2008).

\section{MADM}

Multiple Criteria Decision Making (MCDM) adalah suatu metode pengambilan keputusan untuk menetapkan alternatif terbaik dari sejumlah alternatif berdasarkan beberapa kriteria tertentu. Berdasarkan tujuannya, MCDM dapat dibagi menjadi dua model (Zimmermann, 1991): Multiple Attribute Decision Making (MADM) dan Multi Objective Decision Making (MODM).

Multiple Attribute Decision Making (MADM) digunakan untuk menyelesaikan masalah - masalah dalam ruang diskret. Oleh karena itu pada Multiple Attribute Decision Making (MADM ) biasanya digunakan untuk melakukan penilaian atau seleksi terhadap beberapa alternatif dalam jumlah yang terbatas. Pada dasarnya proses Multiple Attribute Decision Making (MADM) dilakukan melalui tiga tahap, yaitu penyusunan komponen komponen situasi,analisis, dan sintetis informasi (Rudolphi, 2000).

Pada tahap penyusunan komponen- komponen situasi, akan dibentuk tabel taksiran yang berisi identifikasi alternatif dan spesifikasi tujuan, kriteria dan atribut.

Tahap analisis dilakukan melalui dua langkah. Pertama, mendatangkan taksiran dari besaran yang potensial, kemungkinan dan ketidakpastian yang berhubungan dengan dampak dampak yang mungkin pada setiap alternatif. Kedua, meliputi pemilihan dari preferensi pengambil keputusan untuk setiap nilai, dan ketidak pedulian 
terhadap resiko yang timbul. Sebagian besar pendekatan Multiple Attribute Decision Making (MADM) dilakukan melalui dua langkah, yaitu melakukan agregasi terhadap keputusan keputusan yang tanggap terhadap semua tujuan pada setiap alternatif dan melakukan perangkingan alternatif - altenatif keputusan tersebut berdasarkan hasil agregasi keputusan.

Dengan demikian bisa dikatakan bahwa masalah Multiple Attribute Decision Making (MADM) adalah mengevaluasi $\mathrm{m}$ alternatif $\mathrm{A}_{\mathrm{i}}(\mathrm{i}=1,2, . ., \mathrm{m})$ terhadap sekumpulan atribut atau kriteria $\mathrm{C}_{\mathrm{j}}(\mathrm{j}=1,2, . ., \mathrm{n})$, dimana setiap atribut saling tidak bergantung satu dengan yang lainnya. Matriks keputusan setiap alternatif terhadap setiap atribut $\mathrm{X}$ diberikan sebagai :

$$
\begin{aligned}
& \begin{array}{llll}
\mathrm{X}_{11} & \mathrm{X}_{12} & \ldots & \mathrm{X}_{\mathrm{In}}
\end{array} \\
& \mathrm{X}=\mathrm{X}_{21} \quad \mathrm{X}_{22} \quad \ldots \mathrm{X}_{2 \mathrm{n}} \\
& \begin{array}{llll}
\mathrm{X}_{\mathrm{m} 1} & \mathrm{X}_{\mathrm{m} 2} & \ldots & \mathrm{X}_{\mathrm{mn}}
\end{array}
\end{aligned}
$$

Dimana $X_{\mathrm{ij}}$ merupakan rating kinerja alternatif $\mathrm{ke}-\mathrm{i}$ terhadap atribut ke $-\mathrm{j}$. Nilai bobot yang menunjukkan tingkat kepentingan relatif setiap atribut, diberikan sebagai $\mathrm{W}$ :

$$
\mathrm{W}=\left\{\mathrm{w}_{1}, \mathrm{w}_{2}, \ldots, \mathrm{w}_{\mathrm{n}}\right\}
$$

Rating Kinerja (X) dan nlai bobot (W) merupakan nilai utama yang merepresentasikan preferensi absolut dari pengambil keputusan. Masalah MADM diakhiri dengan proses parankingan untuk mendapatkan alternatif terbaik yang diperoleh berdasarkan nilai keseluruhan preferensi yang diberikan (Yeh, 2002).

TOPSIS (Technique for Order Preference by Similarity to Ideal Solution)
TOPSIS didasarkan pada konsep dimana alternatif terpilih yang terbaik tidak hanya memiliki jarak terpendek dari solusi ideal positif, namun juga memiliki jarak terpanjang dari solusi ideal negatif (Hwang, 1981) (Zeleny, 1982). Konsep ini banyak digunakan pada beberapa model MADM untuk menyelesaikan masalah keputusan secara praktis (Hwang, 1993)(Liang, 1999)(Yeh, 2000). Hal ini disebabkan karena konsepnya sederhana dan mudah dipahami, komputasinya efisien dan memiliki kemampuan untuk mengukur kinerja relatif dari alternatif -alternatif keputusan dalam bentuk matematis yang sederhana.

\section{METODE PENELITIAN}

\section{Perancangan Sistem MADM}

Seperti telah dijelaskan pada pendahuluan, penilaian dilakukan dengan melihat nilai-nilai terhadap indikator Lama Berada Dalam Bisnis, Syarat Modal Untuk Memulai, Jumlah Karyawan, Biaya Operasional, Franchise Fee. Selanjutnya masing-masing indikator tersebut dianggap sebagai kriteria yang akan dijadikan sebagai faktor untuk menentukan waralaba yang akan dipilh. Variabel yang digunakan dalam penelitian ini adalah Lama Berada Dalam Bisnis, Syarat Modal Untuk Memulai, Jumlah Karyawan, Biaya Operasional, Franchise Fee. Sistem menggunakan "what- if" Analysis dalam pengambil keputusan. Analisis ini berangkat dari pertanyaan, Apa yang akan terjadi pada solusi yang dihasilkan jika suatu variabel input, asumsi, atau nilai sebuah parameter berubah.

\section{Kebutuhan Input}

Input untuk melakukan proses pengambilan keputusan dari beberapa alternatif ini dapat dilakukan dengan menggunakan wawancara langsung kepada pemilik waralaba atau 
pengumpulan data waralaba yang bersangkutan dari brosur ataau internet. Input data waralaba disesuaikan dengan kriteria yang ditetapkan, dalam contoh kasus pada paper ini kriteria yang dibutuhkan adalah sebagai berikut:

a. Lama Berada Dalam Bisnis

b. Syarat modal untuk memulai

c. Jumlah karyawan

d. Biaya Operasional Waralaba

e. Ketersediaan bahan baku dan penunjang

f. Francise Fee

Rating kecocokan setiap alternatif pada setiap kriteria di nilai dengan 1 sampai 5 , yaitu :

$1=$ Sangat buruk

$2=$ Buruk

$3=$ Cukup

$4=$ Baik

$5=$ Sangat Baik

Input Preferensi atau tingkat

kepentingan dilakukan oleh pengambil keputusan sesuai dengan tingkat kepentingan dari masing masing kriteria. Nilai tingkat kepentingan setiap kriteria di nilai dengan 1 sampai 5, yaitu :

$1=$ Sangat rendah

$2=$ Rendah

$3=$ Cukup

$4=$ Tinggi

$5=$ Sangat Tinggi

Kebutuhan Output

Output atau keluaran yang dihasilkan dari penelitian ini adalah sebuah alternatif yang memiliki nilai tertinggi dibandingkan dengan alternatif nilai yang lain. Pada penelitian ini hasil keluarannya diambil dari urutan alternatif tertinggi ke alternatif terendah. Hasil akhir yang dikeluarkan oleh program nanti berasal dari nilai setiap kriteria, karena dalam setiap kriteria memiliki nilai yang berbeda-beda.

Kriteria Yang Dibutuhkan

Dalam metode ini ada kriteria yang dibutuhkan untuk menentukan waralaba yang akan dipilih sebagai usaha. Adapun kriterianya adalah:

$\mathrm{C} 1$ = Lama Berada Dalam Bisnis

$\mathrm{C} 2=$ Syarat modal untuk memulai

C3 = Jumlah karyawan

$\mathrm{C} 4=$ Biaya Operasional Waralaba

C5 =Ketersediaan bahan baku dan penunjang

C6 = Francise Fee

Diagram Konteks

Merupakan level tertinggi dari DFD , yang menggambarkan seluruh input ke atau output dari sistem dan memberikan gambaran tentang keseluruhan sistem. Pada DFD level ini user melakukan input data kriteria, data waralaba, data transaksi. Selanjutnya data akan diproses dan Sistem akan menampilkan informasi hasil dukungan keputusan kepada User atau pengambil keputusan.

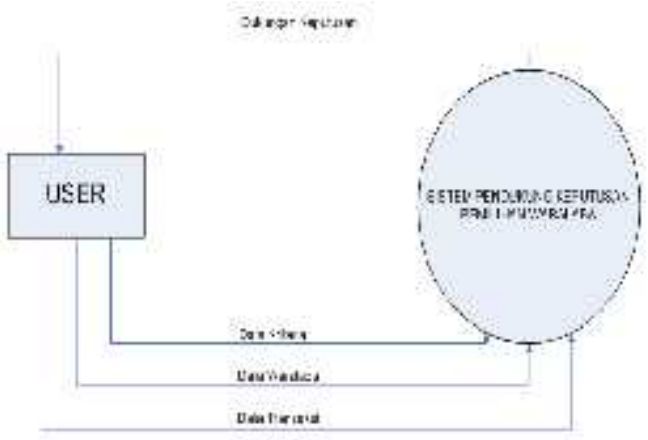

Gambar 1. Diagram Konteks

Rancangan Basis Data

Desain database diperlukan untuk membuat aplikasi Sistem Pendukung Keputusan nantinya. Dalam penelitian ini, desain databasenya adalah sebagai berikut : 


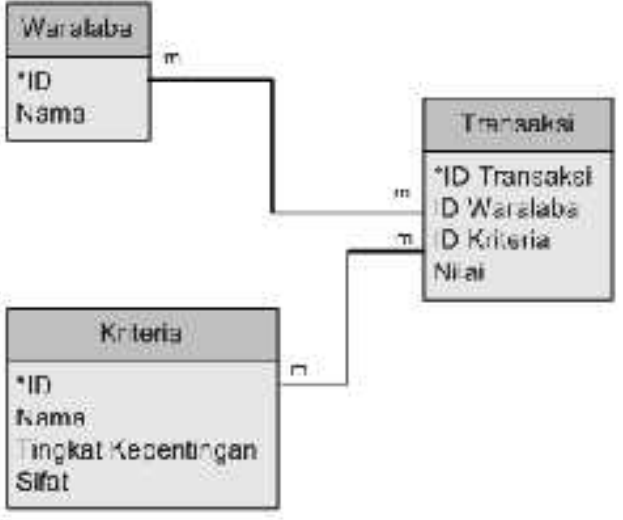

Gambar 2. Rancangan Basis Data

\section{HASIL DAN PEMBAHASAN}

Pada bagian ini akan diberikan sebuah contoh kasus yang diimplementasikan pada sistem yang telah dibuat.

Pak Wahyu, akan memulai bisnis waralaba. Dalam memilih waralaba yang tepat, Pak Wahyu memiliki tiga buah data waralaba yang akan dipilihnya. Data waralaba berdasarkan kriteria kriteria yang di inginkan nya dapat dilihat pada tabel 1 berikut ini :

Tabel 1 Data yang Tersedia

\begin{tabular}{|c|c|c|c|c|c|c|c|}
\hline$x_{0}$ & $\begin{array}{c}\text { Xama } \\
\text { varalabs }\end{array}$ & C & $\begin{array}{l}c \\
2\end{array}$ & C & r & C & C \\
\hline 5 & Isla tola & 3 & $1-000.010$ & 1 & 1.300 .60 & 91 & 20 \\
\hline 2 & Mr berget & 1 & I. 000.000 & 1 & 1 jou.400 & Ct & 10 \\
\hline 3 & $\begin{array}{l}\text { Krluih } \\
\text { Turki }\end{array}$ & 1 & 5) 10000 & 3 & 2. ates $1 \times-\infty$ & $x$ & 10 \\
\hline
\end{tabular}

Untuk menyelesaikan kasus tersebut maka tahapan yang akan dilakukan adalah :

1. Membuat Tabel Rating Kecocokan Tiap Alternatif dan Tiap Kriteria

2. Membangun normalisasi $\mathrm{R}$

3. Membangun normalisasi $Y$

4. Menentukan matriks solusi ideal positif

5. Menentukan matriks solusi ideal negatif

6. Menentukan jarak antara nilai setiap alternatif dengan matriks solusi ideal positif.
7. Menentukan jarak antara nilai setiap alternatif dengan matriks solusi ideal negatif

8. Menentukan jarak antara nilai setiap alternatif dengan matriks solusi ideal positif dan negatif

9. Maka Alternatif yang disarankan adalah Waralaba Mr. Burger dengan nilai $\mathrm{V} 1$ adalah 0,647

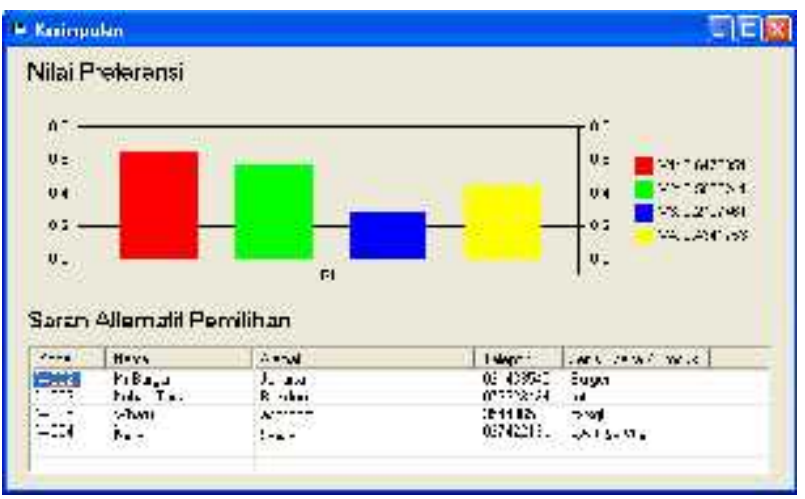

Gambar 3. Alternatif Pemilihan Waralaba

Pada gambar 3 terlihat hasil dari perhitungan menggunakan sistem yang telah dirancang yaitu berupa alternatif pemilihan waralaba.

\section{KESIMPULAN}

Model yang digunakan dalam sistem pendukung keputusan ini adalah Multiple Attribute Decision Making (MADM) dan untuk melakukan perhitungan metode MADM pada kasus tersebut dalam mencari alternatif terbaik berdasarkan kriteria-kriteria yang telah ditentukan mengggunakan metode TOPSIS (Technique for Order Preference by Similarity to Ideal Solution) untuk melakukan perhitungan akan menghasilkan Sistem pendukung keputusan yang membantu memutuskan waralaba yang akan dipilih.

\section{SARAN}

Bagi para peneliti yang berkeinginan untuk 
mengembangkan sistem pendukung keputusan ini dapat membuat tampilan yang lebih user friendly kepada pengguna dan dibuatkan langkah setiap proses perhitungan agar lebih jelas dan mudah dipahami.

\section{Daftar Pustaka}

Abhary, K., Marian, R., Abd, K., 2011, An MCDM Approach to Selection Scheduling Rule in Robotic Flexible Assembly Cells, World Academy of Science, Engineering and Technology.

Hao, L., dan Qing, S.X., 2006, Application of Topsis in The Bidding Evaluation of Manufacturing Enterprises, Proceedings of $e$ ENGDET 2006 5th International Conference on e-Engineering \& Digital Enterprise Technology, Guiyang, Cina.

Herkules, 2010, Sistem Pendukung Keputusan Penentuan Penerima Dana Bantuan Langsung Masyarakat (BLM) Program Nasional Pemberdayaan Masyarakat (PNPM) Mandiri Perdesaan (Studi Kasus : PNPM MPd Selat Kapuas Kalimantan Tengah), Tesis, Program Magister Ilmu Komputer Sekolah Pasca Sarjana Universitas Gadjah Mada, Yogyakarta.

Sukerti, N.K., 2010, Sistem Pendukung Keputusan Penentuan Desa Penerima Bantuan Program Community Based Development (CBD)- Bali Sejahtera Menggunakan Metode TOPSIS, Tesis, Program Pascasarjana Universitas Gadjah Mada, Yogyakarta.

Wu, M., 2007, Topsis-AHP Simulation Model and Its Application to Supply Chain Management, World Journal of Modelling and Simulation, England, UK. 